\title{
MAR Technique to Reverse the Declining Trend of Groundwater Level in Barind Area, NW, Bangladesh
}

\section{Md. Iquebal Hossain 1,2*, Niamul Bari1, Shafi Uddin Miah1, Chowdhury Sarwar Jahan³, Md. Ferozur Rahaman ${ }^{4}$}

${ }^{1}$ Department of Civil Engineering, Rajshahi University of Engineering \& Technology, Rajshahi, Bangladesh

${ }^{2}$ Barind Multipurpose Development Authority, Rajshahi, Bangladesh

${ }^{3}$ Department of Geology and Mining, University Rajshahi, Rajshahi, Bangladesh

${ }^{4}$ Institute of Environmental Science, University of Rajshahi, Rajshahi, Bangladesh

Email: *iquebal_hossain@yahoo.com

How to cite this paper: Hossain, Md.I., Bari, N., Miah, S.U., Jahan, C.S. and Rahaman, Md.F. (2019) MAR Technique to Reverse the Declining Trend of Groundwater Level in Barind Area, NW, Bangladesh. Journal of Water Resource and Protection, 11, 748-757.

https://doi.org/10.4236/jwarp.2019.116045

Received: December 24, 2018

Accepted: June 23, 2019

Published: June 26, 2019

Copyright $\odot 2019$ by author(s) and Scientific Research Publishing Inc. This work is licensed under the Creative Commons Attribution International License (CC BY 4.0).

http://creativecommons.org/licenses/by/4.0/

\begin{abstract}
The study was carried out in the drought prone water stressed Barind area to know the state of rainfall, trend of groundwater level and groundwater management options including Managed Aquifer Recharge (MAR) techniques. Rainfall and groundwater level data have been used and shown a decreasing trend in Godagari and Mohonpur Upazila. But in Niamatpur Upazila rainfall is in reverse condition of rising trend. Decreasing trend of groundwater level (GWL) has been found in the entire study area. The decreasing trend of GWL demands judicious management of groundwater for the area. For recovery of GWL as well as groundwater management, a recharge well as MAR structure has been installed and observed that the situation is better than the before and increasing GWL. More research and study are necessary to know about the trend of groundwater level for the whole Barind area and to introduce proper designed and modified MAR techniques to reverse the declining situation of GWL.
\end{abstract}

\section{Keywords}

Groundwater, Groundwater Level, MAR, Rainfall, Water Management

\section{Introduction}

Water is a precious natural resource. Groundwater is the most essential and valuable resource for agriculture, domestic and industrial purposes. It is an integral part of the water cycle. The cycle starts with precipitation falling on the surface. 
Runoff from precipitation goes directly into lakes and streams. Some of the water which seeps into the ground is used by plants for transpiration. The remaining water drains down through the soil to the saturated zone, where water fills all the spaces between soil particles and rocks, called groundwater. Groundwater is the subsurface water that occurs beneath the water table in the soils and geologic formations that are fully saturated [1]. Safe groundwater abstraction and proper groundwater management are important for sustainability of the resources. A recent study shows that groundwater level in some areas falls between $5-10 \mathrm{~m}$ in dry season and most of the tube wells fail to lift sufficient water [2]. Researchers and policymakers are advocating sustainable development as the best approach to today's and future water problems [3] [4]. With groundwater development, fluctuations will amplify; but as long as rainfall is managed to recharge aquifers, and proactive water saving strategies are put in place, a steady and sustainable state can be achieved [5]. In mainstream irrigation thinking, groundwater recharge is considered as a by-product of flow irrigation, but in today's world, groundwater recharge needs to be understood on its first emergency for making groundwater sustainable integrating all possible options [5]. Various places around the world are currently or potentially experiencing the problem of water shortage due to rapid population growth, water contamination, groundwater exhaustion, and unbalanced allocation of water resources caused by geographical and seasonal variations [6]. Different studies have documented that groundwater level declined substantially during the last decade causing a threat to the sustainability of water use for irrigation in this region and impacting upon other sectors, too [7]. Due to lack of proper knowledge, indiscriminate installation of pumps and non-availability of modern technologies, farmers lift water without thinking future use which causes the declining of groundwater table alarmingly in many areas of Bangladesh. Although the groundwater dominates the total irrigated area, its sustainability is at risk in terms of quantity in the northwest region [8]. Frequent shortage of water in the region has had impacts that can be ranged as economical, social and environmental [9] [10]. Groundwater plays an important role in sustaining Bangladesh's economy, environment, and standard of living. The benefits of utilizing groundwater in developing countries have been clearly demonstrated; aquifers providing a store of groundwater, which, if are utilized and managed effectively, can play a vital role in increased yield resulting reliable irrigation [11]. Presently groundwater based irrigation is adapted to cultivate high-yielding rice variety during dry season in South Asia especially in Bangladesh-the fourth biggest rice-producing country in the world [12] [13]. Here agriculture contributes nearly $15 \%$ of the GDP as rice crops cover $75 \%$ of the cropped areas and contribute over $95 \%$ to the total food grain production. The significant growth in the country's irrigated agriculture has happened in the past decade which resulted ever increasing demand of finally leads to water shortage [14] [15]. Like other natural calamities and disasters such as floods or cyclones in coastal and most part of the country [16] [17] [18] its northwestern part is affected more severely by drought when monsoon ends. 
Barind Tract is a physiographic unit located in north-western part of Bangladesh having gross area of $7727 \mathrm{sq} \mathrm{km}$ [18]. The elevations vary from $47 \mathrm{~m}$ in its central part to $11 \mathrm{~m}$ in the southeast and $9 \mathrm{~m}$ in the northeast [19]. Barind is a drought prone water stressed area. Surface water sources are very limited here. Most of the rivers, pond and other water bodies get dried up during dry season in this area. So, groundwater is the main source which is used for irrigation, drinking and other purposes. A Typical dry climate with comparatively high temperature prevails in Barind area except for the wet season beginning from mid June to October and temperature ranges from $4^{\circ} \mathrm{C}$ to $44^{\circ} \mathrm{C}$. Annual rainfall is very less and varies from $1250 \mathrm{~mm}$ to $2000 \mathrm{~mm}$ and the average annual rainfall is $1418 \mathrm{~mm}$ [20]. Groundwater recharging in Bangladesh mainly occurs by monsoon rainfall and flooding but it is a severely drought prone area as well as the area is under flood free zone [21]. More than 15,000 Deep Tube wells (DTWs) have installed to withdraw groundwater for irrigation [22] with a total number of nearly 23,000 including private owners for drinking and irrigation purposes and this excessive withdrawal of groundwater causes the declining of groundwater table and put threat on its resource sustainability [7] [23] [24] [25].

Permanent decline of groundwater table was observed in some area due to over extraction of groundwater and least natural recharge [20]. Management of groundwater is needed for sustainable use of water for irrigation, drinking and other purposes. So, the present study aims to assess the trend of rainfall and groundwater level and recommend the groundwater level management option.

\section{Study Area}

The study area is mainly Barind located at Godagari and Mohonpur Upazila under Rajshahi District and Niamatpur Upazila under Naogaon district (Upazila and district are the second and third tiers of administrative units in Bangladesh). Topography of the area varies from $10.5 \mathrm{~m}$ PWD to $44.3 \mathrm{~m}$ PWD. The landscape comprises mainly plain in the eastern part, dissected and undulating in the western part. Middle part of the study area is relatively high and uneven. Most of the area is flood free making it suitable for the year round cultivation. The location map of the study area is shown in Figure 1.

\section{Data and Method}

Rainfall and Groundwater level data have been collected from the Barind Multipurpose Development Authority (BMDA). The data are checked for quality and consistency and then processed in the required format. After checking and analyzing the data, hydrographs are drawn and found the trend.

\section{Observations}

\subsection{Rainfall}

Rainfall data are collected from permanent rain gauge stations of Godagari, 


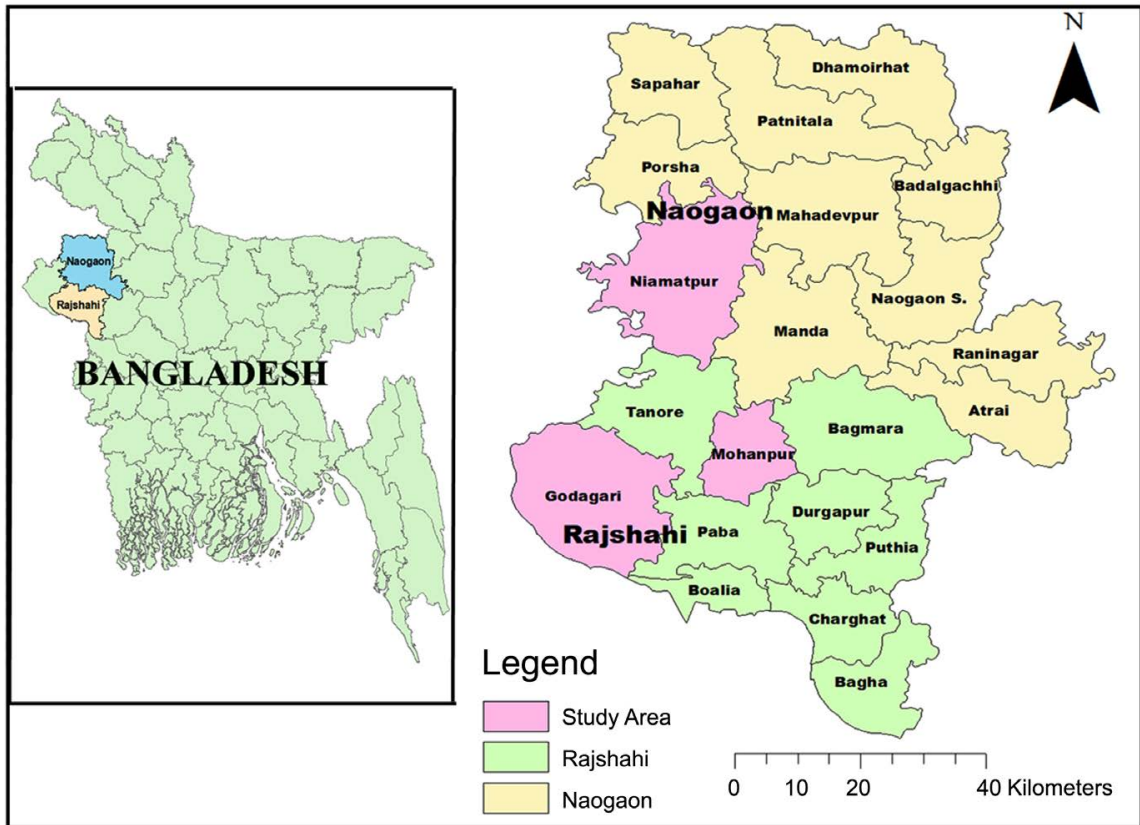

Figure 1. Location map of the study area.

Niamatpur and Mohonpur Upazila office of BMDA for the period of 2002 to 2015. The annual rainfall and the monthly average rainfall are shown in Figure 2 and Figure 3. Figure 2 shows that maximum annual rainfall of Godagari Upazila is $2452 \mathrm{~mm}$ and the minimum annual rainfall is $848 \mathrm{~mm}$ and yearly average rainfall is $1240 \mathrm{~mm}$. For Niamatpur Upazila maximum and minimum annual rainfall are $2295.00 \mathrm{~mm}$ and $886 \mathrm{~mm}$ respectively and yearly average rainfall is $1298 \mathrm{~mm}$. Maximum and minimum annual rainfalls for Mohonpur Upazila are $1400 \mathrm{~mm}$ and $773 \mathrm{~mm}$ and yearly average rainfall is $1088 \mathrm{~mm}$. Figure 3 shows that monthly average maximum rainfall for those three Upazila is $248 \mathrm{~mm}, 269$ $\mathrm{mm}$ and $217 \mathrm{~mm}$ respectively. Decreasing trend in rainfall is observed for both the Godagari and Mohonpur Upazila whereas increasing trend in rainfall is observed for Niamatpur Upazila. If average annual rainfall of these three Upazila is seen (Figure 4), mild increasing trend is observed for the study area. Overall average annual rainfall of the study area is about $1209 \mathrm{~mm}$ which is less than the annual average $(2500 \mathrm{~mm})$ of the country.

\subsection{Groundwater Level}

Groundwater level fluctuation data are collected from the observation wells (OW) of BMDA Godagari, Niamatpur and Mohonpur Zonal office. For Godagari and Mohonpur Upazila data were available for the period of 1995 to 2015 but for Niamatpur Upazila, data were available for the period of 2005 to 2015 . Data are analyzed and presented as the hydrograph. Groundwater depth hydrographs of the entire three Upazilas are shown in Figure 5.

Gradual declining trend in GWL is observed (Figure 5) for all the three Upazilas. Figure 5 shows GWL decreased by about $8 \mathrm{~m}$ and $7 \mathrm{~m}$ in 21 years for Godagari 

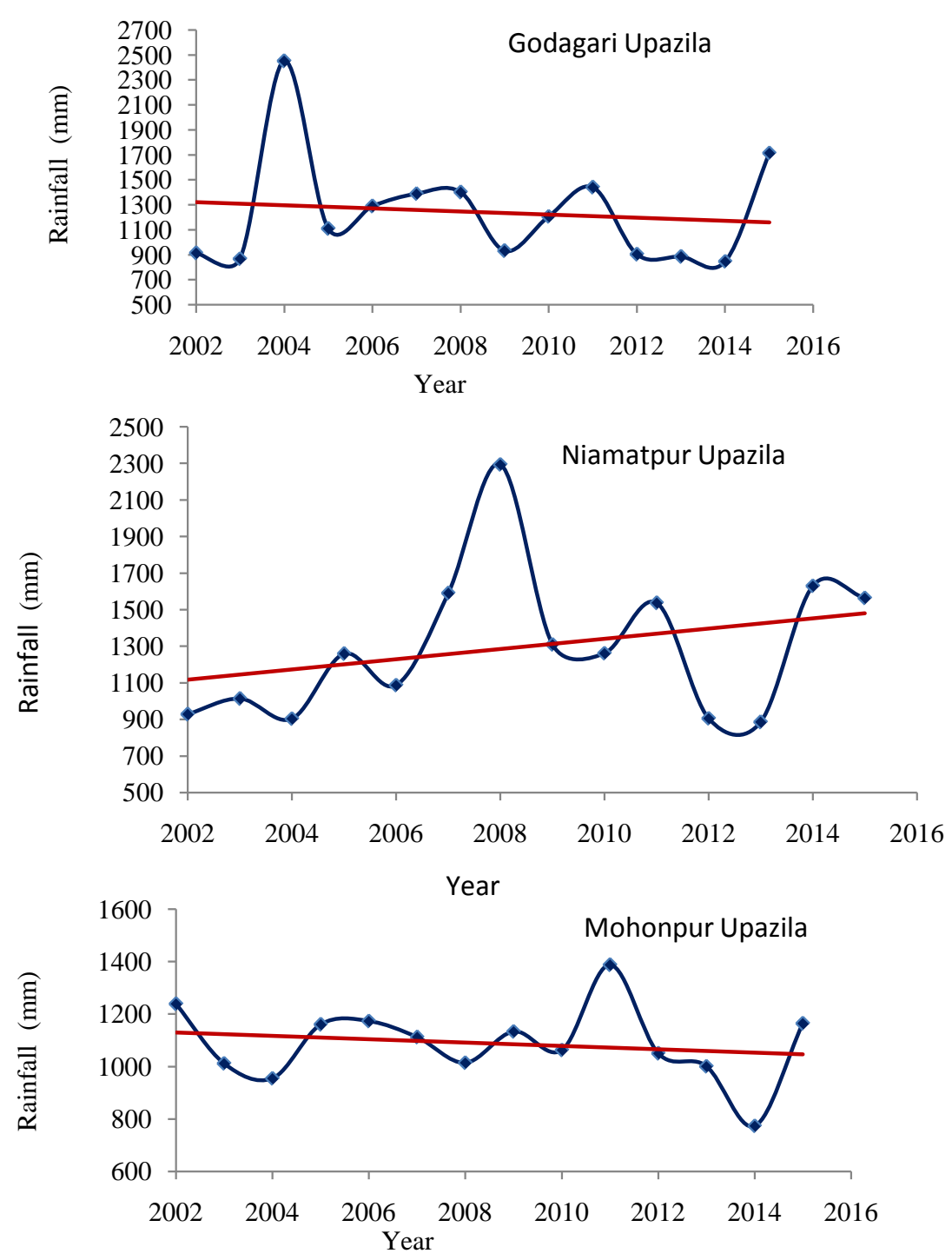

Figure 2. Annual rainfall status of the study area.

and Mohonpur Upazila respectively. For Niamatpur Upazila GWL decreased by about $2.4 \mathrm{~m}$ in 11 years.

\subsection{Groundwater Level Management}

1) Recharge Well as Managed Aquifer Recharged (MAR) technique

In 2013 a Recharge Well (RW) was installed at the bed of re-excavated Sarmangla canal under Godagari Upazila and modified for continuous operation in 2016 and observed the trend of GWL. Water level fluctuation data for the RW are collected and analyzed. The groundwater level hydrograph is shown in Figure 6.

Figure 6 shows that after submergence of the RW and due to recharge of groundwater, GWL level rises and gradual increase in GWL is observed. So, MAR technique as groundwater management option is suitable to reverse the declining trend of groundwater level. 


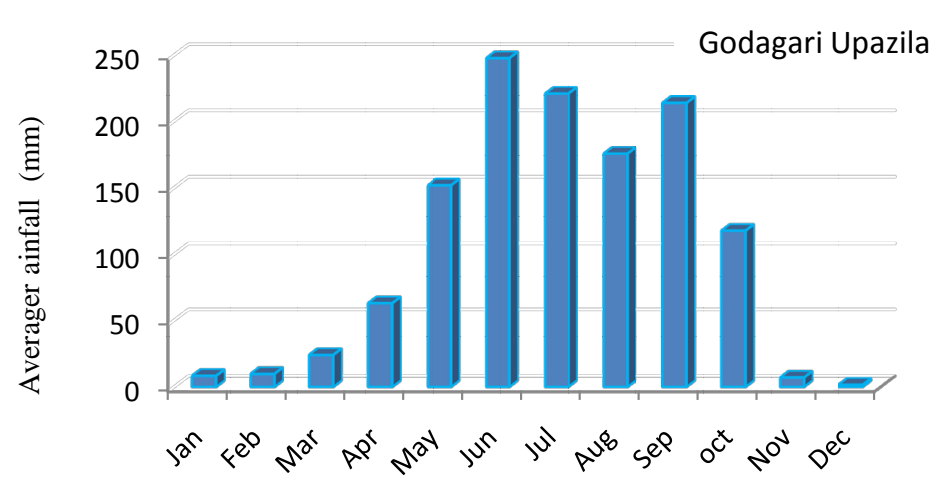

Month

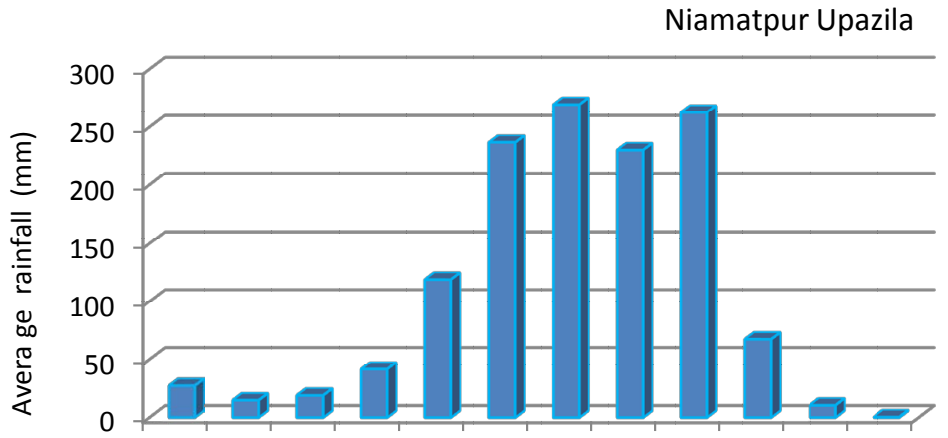

Jan Feb Mar Apr May Jun Jul Aug Sep oct Nov Dec Month

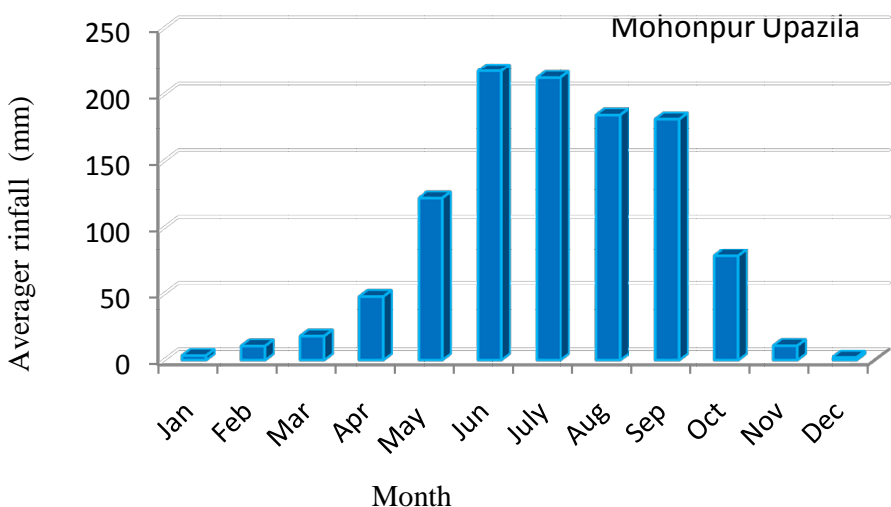

Figure 3. Monthly average rainfall status of the study area.

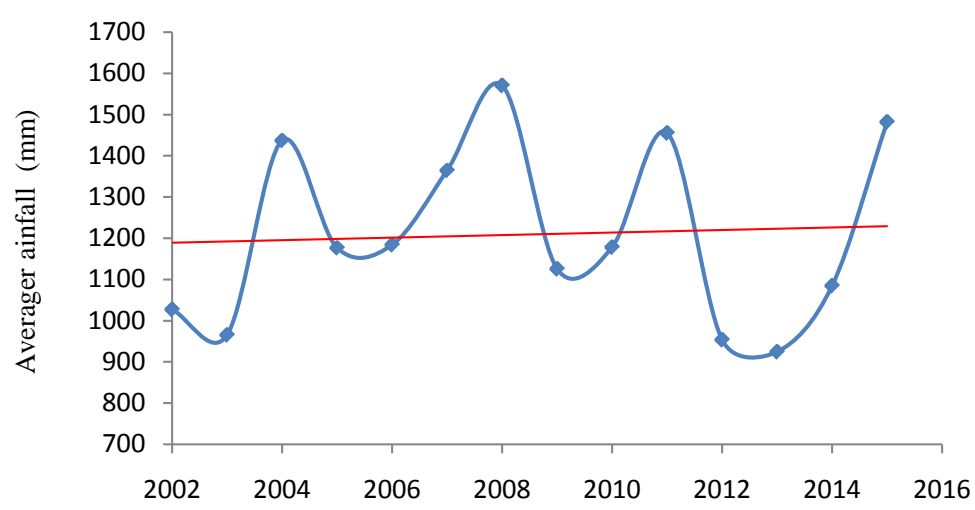

Figure 4. Annual average rainfall trend of the study area. 

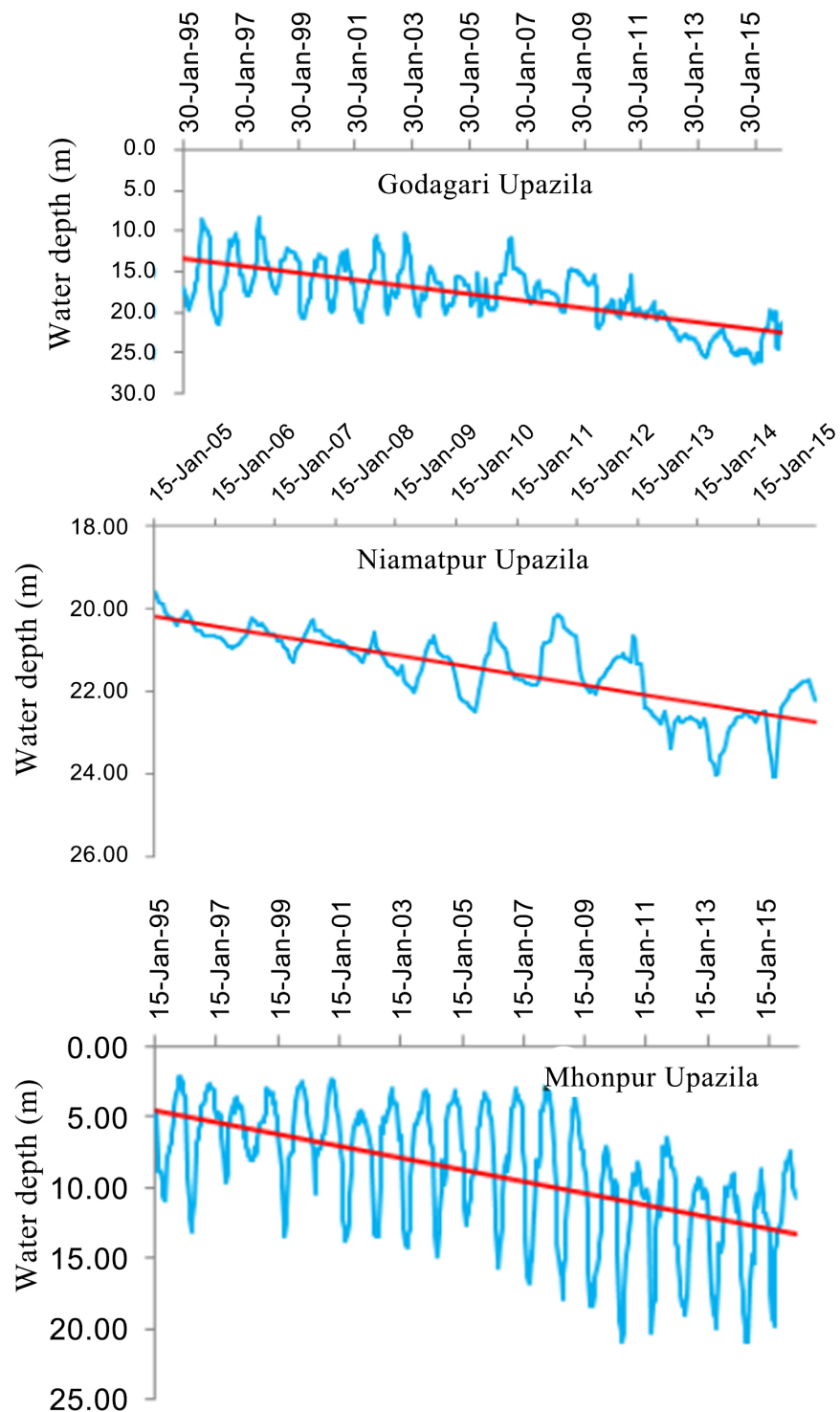

Figure 5. Groundwater level hydrograph of the study area.

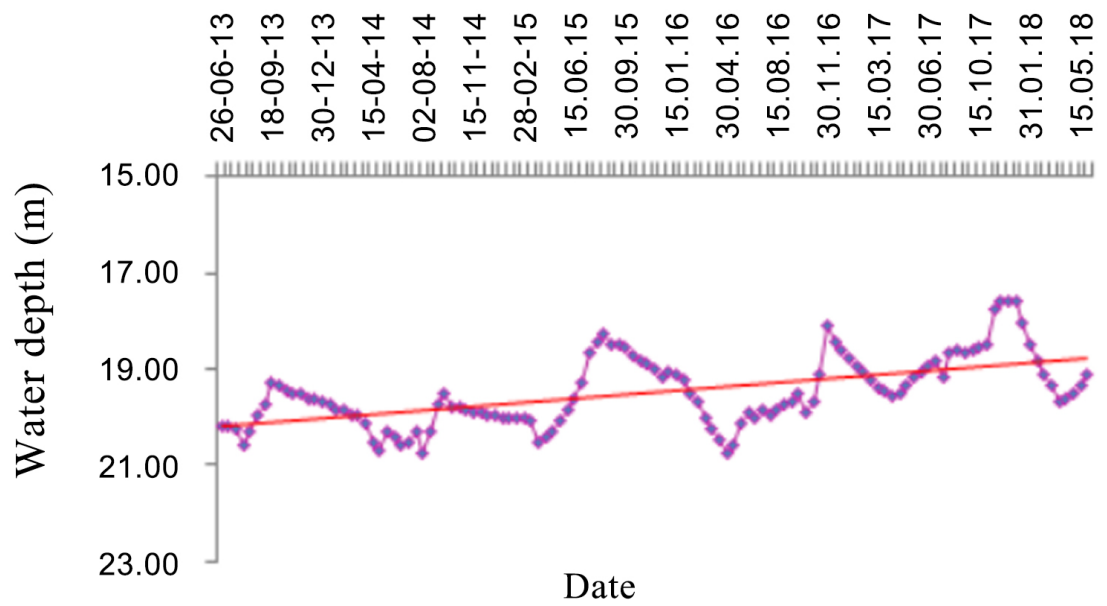

Figure 6. Groundwater level hydrograph for the RW at Godagari Upazila. 
2) Surface water augmentation and efficient irrigation management to reduce the stress on groundwater

Re-excavation of derelict pond, canal and other water bodies for surface water augmentation as well as rainwater conservation has reduced the pressure on withdrawing groundwater for irrigation and introduction of buried pipe irrigation and prepaid meter irrigation system has reduced the irrigation water loss [26].

\section{Conclusion}

There is a proverb for the drought prone water stressed Barind area, "Barind is the land where Life is written in water." Less and uneven distribution of rainfall has further extended the sufferings. Poor surface water sources have made the people dependent on groundwater for irrigation, drinking and other uses. Due to thick clay layer of the top surface storm water cannot percolate easily, so natural recharge is negligible. On the other hand, continuous withdrawing of groundwater causes the declining groundwater level. However, the study results show that annual average rainfall is lower than the country average; gradual decreasing trend in groundwater level; MAR technique increases the GWL reducing the declining trend. Though BMDA has taken so many initiatives to reduce the stress on groundwater through surface water augmentation and devising efficient irrigation management system, groundwater table is going down day by day due to the excessive exploitation of groundwater. MAR technique is a suitable option to reverse the declining trend of groundwater level. So research and study are necessary to design and modify MAR structure for sustainable management of groundwater table in Barind area.

\section{Acknowledgements}

The authors are grateful to Barind Multipurpose Development Authority (BMDA) for the support with different data and cooperation.

\section{Conflicts of Interest}

The authors declare no conflicts of interest regarding the publication of this paper.

\section{References}

[1] Freeze, R.A. and Cherry, J.A. (1979) Groundwater. Prentice-Hall, Englewood Cliffs, $604 \mathrm{p}$.

[2] Dey, N.C. and Ali Arm, M. (2010) Changes in the Use of Safe Water and Water Safety Measures in WASH Intervention Areas of Bangladesh: A Midline Assessment. BRAC-RED Working Paper 27.

[3] Loucks, D.P. (2000) Sustainable Water Resources Management. Water International, 25, 3-11. https://doi.org/10.1080/02508060008686793

[4] Cai, X., McKinney, D.C. and Rosegrant, M.W. (2001) Sustainability Analysis for Irrigation Water Management: Concepts, Methodology, and Application to the Aral 
Sea Region. International Food Policy Research Institute, Washington DC, EPTD Discussion Paper No. 86.

[5] International Water Management Institute (IWMI) (2010) Water Policy Brief Banking of Groundwater in Times of Change. Issue 32.

https://doi.org/10.5337/2010.240

[6] Asano, T. and Cotruvo, J.A. (2004) Groundwater Recharge with Reclaimed Municipal Wastewater: Health and Regulatory Considerations. Water Research, 38, 1941-1951. https://doi.org/10.1016/j.watres.2004.01.023

[7] Jahan, C.S., Mazumder, Q.H., Islam, A.T.M.M. and Adham, M.I. (2010) Impact of Irrigation in Barind Area, Northwest Bangladesh an Evaluation Based on the Meteorological Parameters and Fluctuation Trend in Groundwater Table. Journal Geological Society of India, 76, 134-142. https://doi.org/10.1007/s12594-010-0085-x

[8] Simonovic, S.P. (1997) Risk in Sustainable Water Resources Management. In: Sustainability of Water Resources under Increasing Uncertainties, Proceedings of Rabat Symposium SI, No. 240, 3-17.

[9] Takara, K. and Ikebuchi, S. (1997) Japan's 1994 Drought in Terms of Drought Duration Curve. Proceedings of the 5th Symposium of Water Resources, Japan, 467-477.

[10] Sajjan, A.K., Bhuiyan, M.A. and Dey, N.C. (2002) Impact of 1994-95 Drought in the Northwest of Bangladesh through Questionnaire Survey. In: Proceedings of the 2 nd Annual Paper Meet of Ag. Eng. Division, Institution of Engineers, Bangladesh, 31-35.

[11] British Geological Survey (2002) The Effectiveness of Artificial Recharge of Groundwater: A Review.

[12] Scott, C.A. and Sharma, B. (2009) Energy Supply and the Expansion of Groundwater Irrigation in the Indus-Ganges Basin. International Journal of River Basin Management, 7, 119-124. https://doi.org/10.1080/15715124.2009.9635374

[13] IRRI (International Rice Research Institute) (2010) World Rice Statistics (WRS). Manila, Philippines, 3.

[14] De Villiers, M. (2000) Water: The Fate of Our Most Precious Resource. Mariner Books, Houghton, Mifflin, Boston.

[15] Tsakiris, G. (2004) Water Resources Management Trends, Prospects and Limitations. Proceedings of the EWRA Symposium on Water Resources Management: Risks and Challenges for the 21 st Century, Izmir, 2-4 September, 1-6.

[16] Brammer, H. (1987) Drought in Bangladesh: Lessons for Planners and administrators. Disasters, 11, 21-29. https://doi.org/10.1111/j.1467-7717.1987.tb00611.x

[17] Alexander, D. (1995) Changing Perspectives on Natural Hazards in Bangladesh. Natural Hazards Observation Journal, 10, 1-2.

[18] Rasheed, K.B.S. (2008) Bangladesh Resource and Environmental Profile Hardcover. https://www.amazon.com/Bangladesh-Resource-Environmental-ProfileSajjadur/dp/ B0062VHID

[19] IWM (2006) Groundwater Model Study for Deep Tubewell Installation Project in Barind Area. Final Report, Volume I.

[20] IWM (2012) Groundwater Resources Study and Decision Support System Development of Rajshahi, Naogaon, Chapai Nawabganj, Pabna and Natore Districts and Also Remaining District of Rajshahi Division through Mathematical Model Study for Barind Integrated Area Development Project Phase-III. Final Report, Vol. 1.

[21] Rahman, M. and Mahbub, A.Q.M. (2012) Groundwater Depletion with Expansion 
of Irrigation in Barind Tract: A Case Study of Tanore Upazila. Journal of Water Resource and Protection, 4, 575-567. https://doi.org/10.4236/jwarp.2012.48066

[22] Barind Multipurpose Development Authority (BMDA) (2017-18) Irrigation Status of Rajshahi Division, 2017-2018. Ministry of Agriculture, Dhaka.

[23] Rahman, A.T.M.S., Kamruzzaman, M., Jahan C.S., Mazumder, Q.H. and Hossain, A. (2016) Evaluation of Spatio-Temporal Dynamics of Water Table in NW Bangladesh-An Integrated Approach of GIS and Statistics. Sustainable Water Resources Management, 2, 297-312. https://doi.org/10.1007/s40899-016-0057-4

[24] Rahman, A.T.M.S., Kamruzzaman, M., Jahan, C.S. and Mazumder, Q.H. (2016) Long-Term Trend Analysis of Water Table Using "MAKESENS" Model and Sustainability of Groundwater Resources in Drought Prone Barind Area, NW Bangladesh. Journal of Geological Society of India, 87, 179-193.

https://doi.org/10.1007/s12594-016-0386-9

[25] Rahman, A.T.M.S., Jahan, C.S., Mazumder, Q.H., Kamruzzaman, M. and Hosono, T. (2017) Drought Analysis and Its Implication in Sustainable Water Resource Management in Barind Area, Bangladesh. Journal of Geological Society of India, 89, 47-56. https://doi.org/10.1007/s12594-017-0557-3

[26] Rashid, M.A. and Hossain, M.I. (2019) Irrigation Management System of BMDA: An Innovative Approach. 2nd International Conference on Planning, Architecture \& Civil Engineering, Rajshahi, 7-9 February 2019, 37-51. 